\title{
IMPLEMENTATION OF BIM-TECHNOLOGIES IN RUSSIAN CONSTRUCTION INDUSTRY ACCORDING TO THE INTERNATIONAL EXPERIENCE
}

\author{
Alexander Ginzburg* \\ Moscow State University of Civil Engineering, Moscow, Russia \\ Liubov Shilova \\ Moscow State University of Civil Engineering, Moscow, Russia \\ Aleksey Adamtsevich \\ Moscow State University of Civil Engineering, Moscow, Russia \\ Leonid Shilov \\ Moscow State University of Civil Engineering, Moscow, Russia
}

This article considers the main stages of life cycle of construction project's informational model. The main trends of using various constructions' informational models are revealed and the domestic and foreign experience of implementing BIM technology is analyzed. The maturity levels of BIM technologies are considered according to the Bew Richards model of BIM implementation. It helps to make an analysis of currently used software

Key words: Informational model; BIM- technologies; Life cycle of construction project's informational model

\section{INTRODUCTION}

More effective methods of designing buildings and structures and new building materials are created for improving the quality of the building structures erection. Today BIM-technologies or so-called information models of buildings and structures are one of the most striking innovations in the construction industry.

Currently, the main purpose of using BIM-technologies is to support the building project by using 3D models during its full life cycle.

It is considered that the life cycle of the building project's information model consists of the following stages:

- Initial design;

- Designing (during this stage 3D model is created, an engineering analysis of construction decision is carried out, graphical representation and tabular of the project are formed);

- Building and construction, including management of the procurement process, construction, installation, construction schedule of works, etc ...;

- Operation of a building project, including ef- fective control over the object, taking into account relevant technical information;

- Reconstruction and demolition.

This way Building Informational Modeling (BIM) is a special organized information system about the project, which has a numerical description and can be used on the design and construction stages and even in the period of its operation and during its demolition

\section{INTERNATIONAL EXPERIENCE IN THE FIELD OF INFORMATION MODELING IMPLEMENTATION}

Large experience is accumulated in the field of information modeling implementation all over the world [01-14, 16]. It is important to know that often this experience has been gained with state support. For example, using BIM-technologies is a required condition for getting state budget orders in Great Britain, Denmark, Norway and Finland from this year.

The issue about state support for using BIMtechnologies has matured in Chine too, where thanks to BIM-technologies the stadium for water sports was built during preparation for the 
Olympic Games in 2008. This object consists of 22,000 beams of rays, none of which has a rectilinear shape.

The rate of BIM-technologies introduction increases in North America and South-East Asia. The revival apparent of BIM-technologies using is noted in Russia, too. But in our country only large companies and companies with state participation use these technologies. Today Rosenergoatom is a leader of the BIM-technologies implementation [15]. The company introduced an innovative project management system for the complex engineering objects construction - Multi-D.

\section{THE ASSESSMENT OF BIM- TECHNOLOGIES IMPLEMENTATION LEVEL}

BIM-technologies are constantly evolving, so it is necessary to make an assessment of their implementation taking into account their level of development. It helps us to understand what software can be used during doing our building project.

And abroad the maturity levels of BIM technologies are usually considered according to the Bew Richards model of BIM implementation, which is presented in Figure 1.

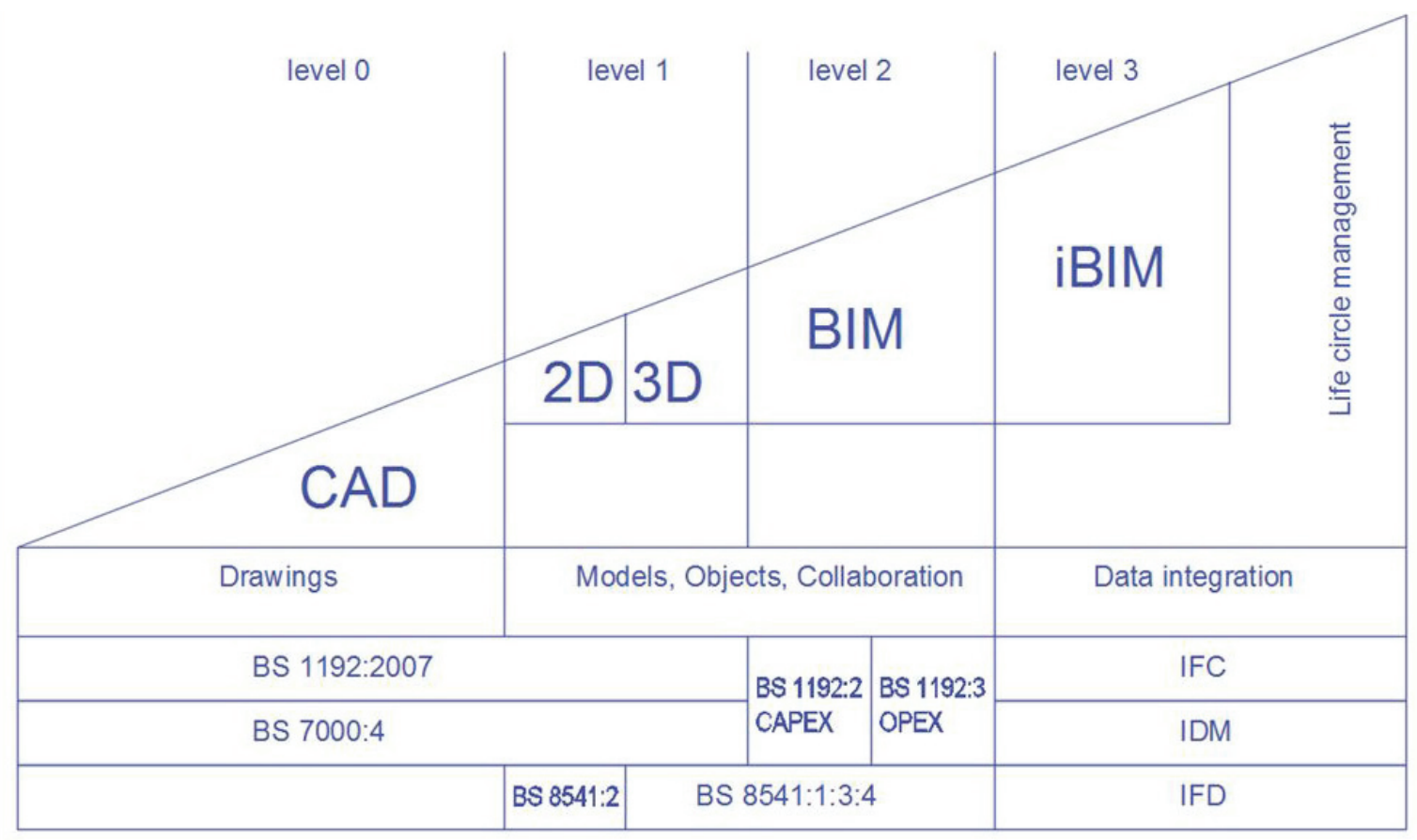

Figure 1: The Bew Richards model of BIM implementation.

According to the Bew Richards model next 4 levels of BIM-technologies implementation are allocated:

The zero level (it is flat CAD without three-dimensional data). Designers can create just flat traditional drawing by using programs of this level. This software can't help to calculate the amount of work or any specifications. The interaction between designers is not provided in these programs. The first level (it is controlled $2 \mathrm{D}$ or $3 \mathrm{D} C A D$ ). Programs of the first level are a mixture of 3D models (which can be used for creating concepts) and 2D models (which can be used for preparing project's documentation). Therefore the relationship between the various sections of the documentation is not provided. Packs of cost management are not implemented in this software. And at the same time the work on drawing bases on BS1192:2007 standard. The second level (It is controlled 3D environment). If the program refers to the second level, interaction between the different sections of the design is provided by the common file formats. Here is full interconnection between drawings and 3D models. The work on drawing bases on PAS 1192-2:2013 standard and other parts of BS1192:2007 standard which aren't used in the first level.

The third level (it is integrated and unified 3Denvironmet). The third level is for full integrate Building Informational Modeling. All production departments work with one common model. The work is based on ISO standards which are specifically developed for rules of BIM-technologies using. 
THE ASSESSMENT OF BIM-TECHNOLOGIES SOFTWARE ACCORDING TO THE BEW RICHARDS MODEL

We consider the main software products according to the Bew-Richards model. Graphisoft Archicad, Autodesk Revit, Nemetschek Allplan are the leaders of the software market in the field of information models.

At the same time the development of ArchiCAD started in 1982, and since 1987 this company has started to introduce the concept of "Virtual Building". So, ArchiCAD can be considered as the first attempt of BIM concept realization. And even 30 years later this software is not a complete solution because It doesn't cover all the building sections completely.

In 1984 NemetschekAllplan program was created, which was originally developed as a program for 3D modeling. But later NemetschekAllplan has been upgraded. And now designers can work with all sections of the building project using this program.

Revit platform by Autodesk is other software for informational modeling.

Autodesk stands behind the popularization of BIM-technologies. And Autodesk Revit covers all main parts of building project. So there is no problem during creation building project thanks to common file format. In Russian Federation CJSC «Nanosoft» was created in 2008. This company is producing software products for the construction of the individual parts of the project (engineering systems).

In 2014 ASCON Company has released program Renga. This software has all principles of full-fledged BIM- solutions, but at the moment only architectural part is worked best of all.

ArchiCAD and Revit are the closest to the second level thanks to their complex approach. These programs allow you to work with the building project as the database. However, while BIM software will not be related to the financial systems and building project management systems, and visualization of construction schedule of works and automatic search of mistakes will not be implemented, the second level is theoretical.

In Russian Federation the bulk of the designers in the field of civil engineering are at the first level now (Fig.1). Today, however, Russia has all chances to go to the second level and further to the third level. Of course, this is absolutely evolution and time-consuming process. And it is necessary to develop own intellectual tools for each design specialty and link them into a single technological process.

Ranging of BIM software is presented in Table 1.

Table 1: The assessment of software for building informational modeling according to the Bew Richards model of BIM implementation

\begin{tabular}{|c|c|c|c|c|}
\hline & $\begin{array}{c}\text { Architectural } \\
\text { part }\end{array}$ & $\begin{array}{c}\text { Constructive } \\
\text { part }\end{array}$ & $\begin{array}{c}\text { Engineering } \\
\text { systems }\end{array}$ & Estimate documentation \\
\hline Graphisoft Archicad & + & & + & \\
\hline Autodesk Revit & + & + & + & + \\
\hline Nemetschek Allplan & + & + & & + \\
\hline CJSC «Nanosoft» & & & + & \\
\hline ASCON Renga & + & & & \\
\hline
\end{tabular}

We can make a conclusion that nowadays there are no solutions which can support the project at the operational stage according to the Table 1. And as a result, none of them can be a complete BIM solution. But it should be considered, that software is improved continuously by the company and it is obviously that a complete BIM solution will be developed soon.

\section{CONCLUSION}

Today, there are a lot of new challenges during creation of building projects, such as the reconstruction of previously constructed facilities, the reduction of terms of designing new building projects taking into account the density of urban development, etc. So there is a real necessity for developing the existing CAD system, where changes in some parameters of the projected building model will entail adjusting the entire model as a whole, without any extra effort. 
In addition, on the $12^{\text {th }}$ of December in 2014 the Decree №926 «On approval of the plan of implementation stages of BIM-technologies in the field of industrial and civil construction» was approved by the Ministry of Construction and Housing and Utilities of the Russian Federation.

All these facts evidence about the favorable conditions for the development of information models using. And in Russia the positive trend in the development of BIM-technologies suggests that in the near future these technologies will be implemented in the different design organizations.

\section{REFERENCES}

1) Weisheng Lu, Chris Webster, Ke Chen, Xiaoling Zhang, Xi Chen Computational Building Information Modelling for construction waste management: Moving from rhetoric to reality//Renewable and Sustainable Energy Reviews Vol.68, Part 1, 2017, 587-595

2) Robert Howard, Luis Restrepo, Chen-Yu Chang Addressing individual perceptions: An application of the unified theory of acceptance and use of technology to building information modelling //International Journal of Project Management Vol.35, Iss. 2, 2017, 107-120

3) Kun-Chi Wang, Wei-Chih Wang, Han-Hsiang Wang, Pei-Yuan Hsu, Wei-Hao Wu, ChengJu Kung Applying building information modeling to integrate schedule and cost for establishing construction progress curves// Automation in Construction, Vol.72, Part 3, 2016, 397-410

4) Nor Diana Aziz, Abdul Hadi Nawawi, Nor Rima Muhamad Ariff Building Information Modelling (BIM) in Facilities Management: Opportunities to be Considered by Facility Managers // Procedia - Social and Behavioral Sciences, Vol. 234, 2016, 353-362

5) Olufolahan Oduyemi, Michael Okoroh Building performance modelling for sustainable building design // International Journal of Sustainable Built Environment, Vol. 5, Iss. 2, 461-469

6) Behnam Atazadeh, Mohsen Kalantari, Abbas Rajabifard, Serene Ho Modelling building ownership boundaries within BIM environment: A case study in Victoria, Australia // Computers, Environment and Urban Systems, Vol. 61, Part A, 2017, 24-38
7) Paweł Nowak, Mariola Książek, Marcin Draps, Jacek Zawistowski Decision Making with Use of Building Information Modeling// Procedia Engineering, Volume 153, 2016, 519-526.

8) Rahimi A. Rahman, Suleiman Alsafouri, Pingbo Tang, Steven K. Ayer Comparing Building Information Modeling Skills of Project Managers and BIM Managers Based on Social Media Analysis// Procedia Engineering, Vol. 145, 2016, 812-819

9) Shih-Hsu Wang, Wei-Chih Wang, Kun-Chi Wang, Shih-Yu Shih Applying building information modeling to support fire safety management// Automation in Construction, Vol.59, 2015, 158-167

10) Sha Liu, Xianhai Meng, Chiming Tam Building information modeling based building design optimization for sustainability // Energy and Buildings, Vol. 105, 2015, 139-153

11) Dong-Woo Ryu, Jung In Kim, Sunduck Suh, Wonho Suh Evaluating risks using simulated annealing and Building Information Modeling // Applied Mathematical Modelling, Vol. 39, Issue 19, 2015, 5925-5935

12) Daniel Ladenhauf, Kurt Battisti, René Berndt, Eva Eggeling, Dieter W. Fellner, Markus Gratzl-Michlmair, Torsten Ullrich Computational geometry in the context of building information modeling // Energy and Buildings, Vol. 115, 2016, 78-84

13) Volkov A., Losev Yu., Losev K. Informacionnaya poddergka giznennogo cikla ob'ektov stroitelstva// Vestnik MGSU, №11, 2012, 253-258

14) gnatova E., El Sheih A. Sostavlenie 4D grafica stroitelstva na osnove BIM // Estestvennie i tekhnicheskie nauki, №11, 2014, 265-267

15) Kupriyanovskii V, Tishenko P., Sinyagov S., Raevskiy M., Savelyev S. i dr. BIM - osnovi i preimushestva primeneniya tekhnologii // ArcReview, №2 (73), 2015

16) Trofimova L., Trofimov V. Informacionnoe modelirovanie i I nginiringovie schemi organizacii ypravleniya kak osnova innovacionnogo razvitiya stroitelnoy otrasli // Vestnik Omskogo universiteta №3,2016, 77-82

Paper sent to revision: 30.07.2016.

Paper ready for publication: 15.12.2016. 